\title{
How Social Inclusion Promotes Sales: An Analysis of the Example of Employing People with Disabilities
}

\author{
Boris Miethlich and Anett G. Oldenburg
}

Comenius University in Bratislava, Faculty of Management, Bratislava, Slovak Republic

Correspondence should be addressed to: Boris Miethlich ; boris.miethlich@fm.uniba.sk

Received date:18 April 2019; Accepted date:23 July 2019; Published date: 6 September 2019

Academic Editor: Radu. D. Stanciu

Copyright (C) 2019. Boris Miethlich and Anett G. Oldenburg. Distributed under Creative Commons CC-BY 4.0

\begin{abstract}
Although social inclusion is an important aspect of corporate social responsibility (CSR), it has received little attention in the literature and research on the subject. However, it is increasingly recognized that more attention needs to be paid to this area: When making purchasing decisions, customers are increasingly looking for companies that act (and credibly demonstrate) in a sustainable and socially responsible manner. Customers are more aware of product-related CSR activities than philanthropy or sustainable business initiatives. Therefore, CSR is an interesting marketing instrument that can be used for competitor differentiation. This article aims to analyse how the promotion of social inclusion could affect the turnover of companies, using the example of the employment of people with disabilities (PWD). The research is based on a literature review using deductive content analysis. The results show that social inclusion, as part of the CSR strategy, contributes to sales growth. This aspect is particularly relevant when it comes to services and direct customer contact. The most important point here is that the company reflects the diversity of its existing and potential customers. In this way, new customers can be won, customer loyalty can be promoted or strengthened, and in return, sales can be increased. CSR activities that are used as a marketing tool for differentiation and that do not only pursue the goal of strengthening the company's reputation can achieve sustainable competitive advantage, a higher market share, open new market segments, and ultimately increase sales permanently.
\end{abstract}

Keywords: social inclusion, disability management, persons with disabilities, CSR

\section{Introduction}

Employment is considered one of the important aspects of social inclusion
(Kuznetsova 2012; Bennett, 2011; Werner 2009; Wynne and McAnaney, 2004). That is especially important for the employment of persons with disabilities in the mainstream

Cite this Article as: Boris Miethlich and Anett G. Oldenburg (2019), " How Social Inclusion Promotes Sales: An Analysis of the Example of Employing People with Disabilities", Journal of Marketing Research and Case Studies, Vol. 2019 (2019), Article ID 463316, DOI: 10.5171/2019.463316 
labor market (Kuznetsova, 2012). It is estimated that in each country 10 to 20 percent of the population is affected by disabilities (Collins, 2007). Despite all efforts (e.g., legal provisions, antidiscrimination, equal treatment), PWD continue to be affected by unemployment to an above-average extent (Markel and Barclay, 2009). The PWD segment is a mostly untapped market for products and services (Collins, 2007) as well as an enormous untapped workforce potential (Buys, Matthews and Randall, 2015). The exclusion of disadvantaged groups, like PWD, can be seen from a value chain perspective as a waste of resources on an individual, entrepreneurial, national and global level (Dyda, 2008). Disability is still one of the characteristics that is distinguishing persons and groups from each other, exposing them simultaneously to social, economic, and political exclusion and discrimination (Klimczuk, 2013). A difficult economic environment seems to further undermine and weaken PWD's equal opportunities (Morger, 2006). Therefore, it is not surprising that PWD, with the same professional qualifications as persons without disabilities, have lower career prospects (Lindsay et al., 2018; Berthoud, 2008).

PWD are often completely excluded from the labor market, which simultaneously leads to an exclusion from social life (Barnes and Mercer, 2005). When the condition of employees impacts on their capacity to do their job, employers can help to continue work and contribute significantly to preventing them entering the process of social exclusion (Wynne, 2004) through measures like vocational rehabilitation or disability management. Studies also show that vocational rehabilitation or disability management reduces overall disability rates and health costs (Cullen, Silverstein and Foley, 2008). Alone a positive social response to disability in the workplace reduces the stigma and threat of job loss for the affected significantly (Cullen et al., 2008; Millington et al., 2003).

The employment of disadvantaged groups can minimize social and health costs for society in the long term and secure the professional future of those affected (Miethlich and Slahor, 2018a). For these reasons, from an individual as well as a social point of view, there is a need to create more mainstream jobs for PWD in order to integrate them into society (Csillag and Gyori, 2016).

The employment of socially excluded groups leads to better economic, social, and geographical integration, due to the increased financial possibilities of the affected persons (Werner, 2009). In contrast, exclusion from the labor market often leads to exclusion from social life (Barnes and Mercer, 2005). Social exclusion arises specifically as a consequence of a health impairment constraint that impairs a person's ability to work and simultaneously reduces their income (Wynne and McAnaney, 2004). As a result, participation in society is severely restricted, for economic reasons but also due to a lack of social contacts.

It was proven by various western countries that legislation alone is insufficient for promoting the employment of PWD. Companies rarely implement legal directives and guidelines and do not claim government support, probably due to inexperience (Wiggett-Barnard and Swartz, 2012; Vilchinsky and Findler, 2004). Promoting employment and inclusion of PWD should be an integral part of a company's social engagement (Monachino and Moreiram, 2014; Markel and Barclay, 2009). Therefore, it is an important social responsibility which needs to be addressed through corporate social responsibility (CSR) strategies (Kuznetsova, 2012). Some companies operate sheltered work centers or other separate employment opportunities for PWD or regularly place orders in sheltered work centers to promote the employment of PWD (SegoviaSan-Juan, Saavedra and Fernández-deTejada, 2017). The idea of promoting social inclusion through CSR is largely absent in the literature, and there is only little empirical research on the concept and practice of CSR regarding social inclusion (Bennett, 2011). Also, the employment of PWD has so far received only little attention in the literature on CSR (Csillag, Gyori and 
Matolay, 2018; Pérez, Romeo and YepesBaldó, 2018; Markel and Barclay, 2009). Although there is a growing interest of a comprehensive understanding of the implementation of CSR initiatives in the past two decades (Wang et al., 2016), there is only little reference in the literature on the implementation and adaptation of the employment of PWD as a CSR initiative. In business practice, the employment of PWD hardly seems to be a topic (Csillag et al., 2018). However, in the literature, various indications that PWD employment has a positive impact on business success can be found (Lindsay et al., 2018).

CSR enables product differentiation (Boehe and Cruz, 2010). However, customers have a preference and greater awareness for product-related CSR activities than for philanthropy or a company's sustainability program (Peloza and Shang, 2011). Accordingly, high-profile CSR initiatives can make a greater contribution to sales than the integration of CSR in all business processes (Bergius, 2005). This leads to the conclusion that the social inclusion or employment of PWD as a non-product CSR activity can make none or only a small contribution to increasing sales. The aim of this article is to analyse how the promotion of social inclusion through the employment of PWD, addressed as part of the CSR strategy, could impact directly or indirectly on a company's sales figures. The perspective of this study is on the voluntary commitment of companies, with the aim of a socially acceptable generation of profits. The research is based on secondary literature on the employment of PWD in companies, social inclusion, and disability in CSR.

\section{Methods}

The aim of this study is to analyse the representative literature regarding the impact on company sales by promoting social inclusion, using PWD employment as an example, as part of the CSR strategy. The expected results are indications of whether social inclusion affects sales and identify approaches on how this commitment could be implemented in the value creation strategy. The research was conducted by searching the scientific databases: Web of Science and Scopus for published literature since 2000 in the subject areas of business, economics, and management using the following keywords: social inclusion, disability, disability management, and employment of persons with disabilities. Additionally, the reference lists of all previously selected articles were checked to find further studies. The titles, abstracts, and keywords of papers were scanned to identify papers related to CSR, social inclusion, and employment of PWD. For the in-depth analysis, English articles published in peer-reviewed journals, conference proceedings or books describing the business management aspects of the topic were selected. The selected literature was evaluated regarding the impact of the employment of PWD on business sales using a deductive content analysis (Mayring, 2015). The coding was carried out according to the following categories: CSR, innovation, customers, marketing, and sales.

\section{CSR in business practice}

The activities of a company have a direct and indirect economic, ecological, and social impact on all those associated with the company. In the modern world economy, assuming appropriate social responsibility is a social necessity (Marsden and Andriof, 1998). In addition, the public increasingly expects companies to incur social responsibilities. Therefore, the question for companies today is no longer whether CSR activities should take place, but rather how they should be carried out (Smith, 2003). Accordingly, CSR has also gained importance in management research (Schneider, 2015; Lee, 2008).

Nevertheless, the definition of CSR remains vague (Schneider, 2015; Crane, Matten and Spence, 2008; Schwartz and Carroll, 2003). Uniform standards (Peloza and Shang, 2011) or a universal concept (Schneider, 2015) of CSR does not exist. Many studies on CSR explicitly point to the inconsistency of the definition and the different boundaries of the concept (Crane et al., 2008). The differences in definition can be attributed in part to historical differences in the 
respective political, social, and cultural environments (Matten and Moon, 2008). However, the literature also shows that the definition and concept of CSR has gradually changed over time from an altruistic to a self-interested or strategic understanding (Perera and Hewege, 2007).

In this analysis, CSR is understood as the voluntary commitment of companies that goes beyond the legal requirements with the aim of generating profits in an ecologically, economically, and socially acceptable manner. As such, CSR is not an additional activity of a company, but a way of operating the core business (Bergius, 2005). The central question is not how profits are distributed, but how they are generated (Leitschuh, 2008). CSR can therefore also be understood as a business process (Maignan and Ferrell, 2004) that is integrated into strategic corporate management. This is intended to enable the company to adapt quickly to changing social conditions, simultaneously securing access to capital, driving forward new markets and thus enabling new growth opportunities (EC, 2011).

A large number of instruments exist to promote the adaptation of CSR in companies, such as corporate guidelines, international standards, certifications, sustainability reporting or comprehensive management systems (EC, 2004). On the other hand, there is only little guidance and knowledge regarding the implementation of specific CSR activities in companies (Peloza and Shang, 2011; Bhattacharya, Korschun and Sen, 2009). Many companies are not aware of the content and impact of CSR (Pérez et al., 2018; Schneider, 2015; Peloza and Shang, 2011). At the same time, the degree to which CSR is implemented within a company is hardly perceived by the public (Baumann-Pauly et al., 2013). It has not yet been adequately identified and researched which aspects promote or hinder the implementation of CSR in a company (Pérez et al., 2018; Baumann-Pauly et al., 2013). It is known, that the success of the implementation depends to a large extent on the quality of internal communication and the implementation itself seems to follow a pattern in relation to the size of the company (Gratzl and Gumpfer, 2017).

There are only a few empirical studies on the effects of CSR activities on business success (Wang et al., 2016; Peloza and Shang, 2011). Those previous investigations have shown inconsistent results (Kraus and Brtitzelmaier, 2012; Peloza and Shang, 2011; Park and Lee, 2009). These results could partly be explained by the qualitative factors that, directly or indirectly, contribute to the added value of a company. These qualitative factors are very difficult to measure and quantify (Miller and Ahrens, 1993). However, the resource-based perspective can be used to show that CSR can lead to a competitive advantage (Branco and Rodrigues, 2006).

Maintaining the comprehensive functionality of the market is part of sustainable corporate management as it forms the basis of all business activities (Elkington, 2007; Porter and Kramer, 2006). The "shared value" approach offers an explanation of how sustainable corporate management or CSR can make a contribution to corporate success and realize competitive advantages. This is assuming that CSR activities can create shared added value for companies and society and, as a result, increase prosperity. Companies that commit themselves can generate an actual "shared value" since the prosperity of a society is increased which will benefit the company in return (Porter and Kramer, 2006).

In business practice, managers have recognized that a socially responsible reputation has a positive influence on business success (Matten and Crane, 2007). Simultaneously, CSR offers a way of differentiation, especially by the possibility of achieving an important, unique, and superior position in the market with a brand (Anselmsson and Johansson, 2007). Consequently, this leads to a strong brand and thus also makes a significant contribution to the company's success (Anselmsson, Bondesson and Melin, 2016). 


\section{CSR as a marketing instrument}

To generate benefits from CSR activities awareness must be created among stakeholders generally and customers specifically (Sen, Bhattacharya and Korschun, 2006). However, some CSR activities can also create value or benefit for the company without the perception of stakeholders. Investments in CSR seem to be worthwhile even if the initial costs of implementation are greater than the resulting profits (Boehe and Cruz, 2010). CSR activities can bring competitive advantages if they succeed in increasing or creating a new customer benefit. Therefore, it is important that management understands how CSR activities affect customers in terms of their overall impression of the company and the benefits that CSR activities bring (Chen et al., 2018; Peloza and Shang, 2011).

Additionally, CSR activities are very well suited as a means of product differentiation (Chen et al., 2018; Boehe and Cruz, 2010; Anselmsson and Johansson, 2007). Customers have developed a preference and a stronger awareness for product-related CSR activities, favoring them over other CSR activities such as philanthropy or sustainable business processes (Chen et al., 2018; Peloza and Shang, 2011). Attributes of a product (i.e., labeling of content and origin, policy implementation, and product liability) form the basis for customers' purchasing decisions, more than aspects of human or environmental responsibility (Anselmsson and Johansson, 2007). Hence, the probability that a customer will become aware of a company's CSR activities is highest for product-related CSR activities (Du, Bhattacharya and Sen, 2007). Therefore, product-related CSR activities have the greatest impact on a company's CSR image. On the other hand, social or people-related responsibility has the greatest influence on customers' buying intentions. Environmental responsibility appears to have the least impact on the CSR image and the least impact on customers' purchasing intentions (Anselmsson and Johansson, 2007).
Human and work-related responsibilities are both dimensions that have the most impact on the overall perceived CSR of the brand. Therefore, this would be the dimensions to prioritize for any brand that wants to achieve a more elaborated CSR image (Anselmsson and Johansson, 2007). The perceived work-related responsibilities are not primarily related to news headlines of bad Human Resource Management (HRM) "practices" among suppliers (e.g., child labor or poor working conditions). In the customer's perception, the treatment of the service employees, to whom they have personal contact, is essential (Anselmsson et al., 2016). Accordingly, HRM and employees also play a role in brand building. A good HRM image can strengthen a brand. Therefore, companies should treat the HRM and employer image, analog to the product and price image. The perception of a company's customers as employers is closely linked to their loyalty and willingness to pay an extra price. Brands with a good HRM image have stronger customer loyalty and attract customers who are willing to pay a premium price. However, the social responsibility dimension in hiring and developing employees is a very important part of a good HRM image (Anselmsson et al., 2016).

Companies can improve their CSR image specifically by placing social responsibility at the center of their value creation strategy (Chen et al., 2018). Studies show, that when a brand presents itself as a CSR-brand, customers are much more aware of CSR activities than they are of a brand that only engages in CSR activities without communicating it as part of the brand (Du et al., 2007). In addition, high-profile CSR initiatives seem to be able to make a more significant contribution to corporate success than, for example, the consistent integration of CSR in all business processes (Bergius, 2005). Nevertheless, CSR activities with high publicity impact achieve positive effects of comparatively short duration. Whereas, the consistent integration of CSR in the value chain brings long-term benefits (Chen et al., 2018) and can secure the existence of a company due to its attitude and credibility even in price-sensitive and highly competitive markets (Gyori and

Boris Miethlich and Anett G. Oldenburg (2019), Journal of Marketing Research and Case Studies, DOI: $10.5171 / 2019.463316$ 
Ocsai, 2014). The positive perception and credibility of a company's social responsibility lead to an overall higher probability of purchase as well as longerterm loyalty and advocacy among customers (Du et al., 2007).

The compatibility of CSR and competition strategies can be guaranteed (Baumgartner and Ebner, 2010). This is based on the competitive strategies according to Porter (2008) and the classification of CSR strategies, which are divided into conservative, visionary, introverted, and extroverted strategies (Baumgartner and Ebner, 2010). The generic strategic principles for achieving a competitive advantage are divided into three fundamental types: the strategy of cost leadership, the strategy of differentiation and the strategy of focus (Porter, 2008). In economics literature, these are generally used under the term competitive strategies, since their aim is to achieve and secure a lasting competitive advantage (Kerth, Asum and Stich, 2015). However, a competitive advantage can only be achieved if entrepreneurial action is based on focusing on one of the two main strategic directions: either on a cost structure that is as favorable as possible or on differentiation. These two strategic options are also known as generic competitive strategies (Porter, 2008). The strategy of focus concentrates on a submarket with a target group that has a specific needs structure (Bea and Haas 2016). Differentiation strategies can be categorized into six systematic methods through which a company can gain a competitive advantage over its competitors. These include the possibilities of differentiating oneself from competitors through price leadership, design, image, quality leadership, additional services and through an undifferentiated strategy (e.g. the pursuit of an imitation strategy) (Mintzberg et al., 2003).

According to Porter (2008) the generic competitive strategic approaches "cost leadership" and "differentiation" are valid throughout a whole industry, while the strategic approach of "focus" is only specific to the respective segment (Porter, 2008). The definition of the market to be served is therefore based on the respective industry or on focusing on a niche (Kerth et al., 2015). A clear understanding of the needs of customers and the market is a prerequisite for achieving competitive advantages. Only if customer needs are met effectively, costefficient, and better than those of competitors a real competitive advantage can be created (Papulova and Papulova, 2006). The quality of the relationships between CSR and competitive strategies is determined to a large extent by two factors: the benefits for stakeholders and the costs incurred by the company. Studies show that the connection between CSR and competitive strategies is also compatible with business practice. For example, a holistic strategy, that focuses on sustainability aspects in all business activities, can bring a competitive advantage through differentiation and innovation. That offers stakeholders, and specifically customers, a unique value proposition (Baumgartner and Ebner, 2010).

\section{Employment of PWD as part of the CSR strategy}

The difficulties that PWD have in the labor market and the failure of government measures to promote the employment of PWD indicate the need to address this issue as part of the CSR strategy of companies (Miethlich and Slahor, 2018b; Kuznetsova, 2012). The promotion of employment and social inclusion of PWD can therefore also be seen as a central component of a company's social commitment to its employees and society (Kuznetsova and Yalcin, 2017; Monachino and Moreiram, 2014; Markel and Barclay, 2009). In their CSR strategies, companies must explicitly formulate how and in what form this concern is addressed. Only in this way a CSR initiative can be successfully implemented. Simultaneously, it is important to communicate and make the commitment and its positive benefits visible within the company and to the outside world (Miethlich and Slahor, 2018b). Nevertheless, the employment of PWD is still rarely part of the CSR strategy in business practice (Csillag and Gyori, 2016). 
In concrete terms, the integration of people with disabilities in companies must be understood as a standardized process aimed at promoting employment of PWD under the same conditions as other workers (Munduate et al., 2014). PWD cannot simply be equated with other disadvantaged groups as part of diversity. Diversity management approaches are not enough and cannot promote equality and equal opportunities for PWD (Woodhams and Danieli, 2000). The main element of the proactive engagement and integration of PWD into the company is the reduction of mental and physical barriers within the company (Hidegh and Csillag, 2013). Theoretically, the employment of PWD is about tailoring each workplace to the needs of PWD and the business context in which they operate (Markel and Barclay, 2009). Individual adjustments at the workplace and working environment according to the disability (Schur, Kruse and Blanck, 2005) or individual aids are often necessary (Markel and Barclay, 2009). However, adjustments to the job profile (Schur et al., 2005) or the general conditions may also be necessary. This includes the need for irregular, adapted or flexible working hours or the possibility of telecommuting (Schur et al., 2014).

Furthermore, a clear commitment to the employment of PWD is not enough, even in the context of a diverse corporate culture. It is essential for the employment of PWD to reduce physical and mental barriers within the company (Miethlich and Slahor, 2018b). The promotion of PWD employment serves as an added value for a company's social responsibility program. On the one hand, the commitment serves society and the company is regarded as a good "corporate citizen". On the other hand, it creates a positive image and makes disabilityfriendly values explicit in the workplace (Millington et al., 2003).

\section{Results}

The results of the deductive summary content analysis of the selected secondary data are described below according to the coded categories: CSR, Innovation, Customers, Marketing and Sales.
CSR: The inclusion of PWD is an important component of CSR (Kuznetsova and Yalcin, 2017). Employment of PWD promotes social inclusion, diversity, and equal opportunities as well as an inclusive corporate culture (Csillag and Gyori, 2016; Aytac et al., 2012; Bennett, 2011). Social inclusion as part of the CSR strategy represents a win-win situation for all stakeholders (Aytac et al., 2012). It also serves the social education of the society regarding the abilities of PWD (Manaf et al., 2018). Additionally, employment of PWD is an indication of a good corporate culture (Schur et al., 2009). The promotion of PWD employment serves as an added value for a company's social responsibility program (Millington et al., 2003), minimizes social and health costs for society in the long term and secures the professional future of those affected. Companies that commit themselves can generate an actual "shared value" since the prosperity of the society is increased which will benefit the company in return (Miethlich and Slahor, 2018a; Papula, Papulová and Papula, 2014).

Innovation: Employment of PWD can make a positive contribution to the company's success (Lindsay et al., 2018; Rosenbaum, Baniya and Seger-Guttmann, 2017; ODEP, 2009). By considering the needs of PWD in their role as employees (Rosenbaum et al., 2017), the customer base of PWD is also promoted (Kuznetsova, 2012). Companies should respond to the needs of customers with disabilities too, as they may need specially designed products and services to be able to benefit from the offer (Sandler and Blanck, 2005; Miethlich, 2018), as well as through high accessibility standards of the companies' buildings and facilities (Kuznetsova and Bento, 2018). The prerequisite for this is to develop increased awareness for the needs and expectations of disabled customers (Lindsay et al., 2018; Miethlich, 2018; Gröschl, 2004). Specifically, the resulting sensitivity to disability allows companies to develop products and services for PWD (Lindsay et al., 2018; Miethlich, 2018; Seino et al., 2017; Kuznetsova, 2012; Ball et al., 2005), which could open new market segments (Miethlich, 2018). PWD as employees bring unique experiences and

Boris Miethlich and Anett G. Oldenburg (2019), Journal of Marketing Research and Case Studies, DOI: $10.5171 / 2019.463316$ 
understanding to the company (ODEP, 2009). Therefore, PWD offers companies the opportunity to renew not only their products but also their structures, processes, management style, and corporate culture, specifically by using new information and communication technology (Migliaccio, 2016). Several studies show that the employment of PWD leads to an increase in creativity (Gröschl, 2007; Dibben et al., 2002), better decision-making processes (Dibben et al., 2002), improved ability to solve problems in companies (Lindsay et al., 2018) and stimulated innovations facilitated through the associated diversity in the teams (ODEP, 2009). PWD themselves are often innovative and creative in how they work with their clients (Bennett, 2011) and seem to have a positive impact on service quality and efficiency (Lindsay et al., 2018).

Customers: The employment of PWD is in itself an opportunity to attract and retain socially responsible customers and customers with disabilities (Lindsay et al., 2018; Gröschl, 2007) and increases the chance to gain a lasting customer base (ODEP, 2009). The employment of PWD recognizes and reflects the diversity of the consumer market respectively society; customers and potential customers (Lindsay et al., 2018; Wells, 2008; Jones and Schmidt, 2004; Dibben et al., 2002). Disability initiatives as socially responsible behavior of a company ensures a good local client base (Dibben et al., 2002): From the hiring of people with visible disabilities, ranging from improving their image with customers and investors to building sustainable relationships through clientemployee contacts (Lysaght, OuelletteKuntz and Lin, 2012) and increasing customer loyalty and satisfaction (Lindsay et al., 2018). The employment of PWD often results in an improvement of the customer relations (Csillag and Gyori, 2016; Kuznetsova, 2012; Graffam et al., 2002) and leads to higher consumer loyalty (Gelashvili, Camacho-Miñano and Segovia-Vargas, 2015). Specifically, more research is needed around guests' attitudes in the hospitality and tourism industry as there is face-to-face communication with employees and the success of the business is highly correlated with the excellence of the service provided. (Kalargyrou, 2014). Guests with disabilities specifically chose business because of the barrier-free environment and the accommodating facilities and because their disabilities are not emphasized by the employees. The barrier-free environment is also appreciated by families with small kids or seniors. (Gröschl, 2013). Concerns regarding PWD and customer contact exist specifically in the high price and luxury segments (Gröschl, 2004). However, generally, the physical attributes of PWD do not negatively influence the experiences of guests (Gröschl, 2013). Online customer reviews of restaurants that employ PWD as "front line employees" are generally favorable and positive. Therefore, employees with disabilities seem to make a significant positive contribution to the perception of service quality. PWD as front line employees can even act as a buffer for service errors and negative customer ratings. However, the disability must be visible or perceptible so that the corresponding reactions are provoked among the customers. (Rosenbaum et al., 2017). Generally, customers are satisfied with the services they receive from people with disabilities (Lindsay et al., 2018). Some clients appreciate and search for the opportunity to meet persons with disabilities (Gröschl, 2013).

Marketing: It is important to communicate the commitment towards the employment of PWD and make its positive benefits visible within the company as well as for the outside world (Miethlich and Slahor, 2018b). This allows benefiting from the advantages that result from its reputation as a good "corporate citizen" or socially responsible company (Miethlich and Slahor, 2018a), like creating a stronger corporate brand (Csillag and Gyori, 2016). Additionally, it leads to strengthening value drivers such as the development of a differentiated reputation with key stakeholders and customers (Kuznetsova, 2012; Gröschl, 2005). Not to forget that PWD can play any stakeholder role: capitalists, lenders, investors, customers/users, suppliers, opinion makers, employees or business operatives (Migliaccio, 2016). 
PWD in direct customer contact can be an important element in creating and maintaining a CSR image and a socially responsible reputation, which is passed on by customers as word-of-mouth propaganda and can also serve as a basis for a responsive and successful marketing program (Rosenbaum et al., 2017). A socially responsible business strategy and employer branding help to demonstrate the company's openness and inclusiveness (Kuznetsova and Yalcin, 2017). The "inclusive" aspect of the businesses could be promoted through the advertising about the employees with disabilities and their performance (Gröschl, 2013). Diversity and inclusive workplaces can be an immanent part of the brand (Csillag and Gyori, 2016; Hull, 2007). Also, a better social image (Gelashvili et al., 2015) leads to good public relations (PR) (Kuznetsova and Yalcin, 2017) as well as an overall positive impact on company image (Lindsay et al., 2018; Csillag and Gyori, 2016) and increased brand loyalty (Lindsay et al., 2018) as well as a stronger brand (Csillag et al., 2018). The employment of PWD can be understood as a subtle way to promote the corporate image and provide more successful marketing to different types of customers (Dibben et al., 2002).

Sales: Customers with disabilities and their families, friends, and associates represent a huge potential market segment. (ODEP, 2009). Different studies show that customers would prefer to give their business to companies that hire people with disabilities (Kalargyrou, 2012). Consumers responded positively towards socially responsible companies. 92 percent of consumers felt more favorable toward companies that hire people with disabilities (Lindsay et al., 2018). Consumers pay more attention to and patronize businesses that feature people with disabilities in their advertising. Disability-friendly businesses often realize the loyal patronage of people with disabilities, their families, and their friends (Rosenbaum et al., 2017). Reflecting the diversity of the consumer market (Lindsay et al., 2018; Wells, 2008; Jones and Schmidt, 2004; Dibben et al., 2002) can attract a wider customer base, increase a company's market share and lead to higher sales (Dibben et al., 2002). Also, the development of new products and services or responding to marketplace needs lead to access of new markets (ODEP, 2009). Previous research shows no direct connection between the employment of PWD and higher profitability; probably because companies mostly understand and use PWD to promote their image and not as a direct "competitive advantage" (Dibben et al., 2002). Nonetheless, the employment of PWD allows obtaining competitive advantages such as value creation. Better Customer relations, stimulated innovations, a strong socially responsible brand and differentiated corporate culture result in higher profits (Gelashvili et al., 2015) which is confirmed by various practical examples (Kalargyrou, 2014).

\section{Conclusion}

This study aimed to analyse the impact on company sales by promoting social inclusion, using PWD employment as an example, as part of the CSR strategy. The perspective of this study was on the voluntary commitment of companies, with the aim of a socially acceptable generation of profits.

The analysis of the state of research shows that the promotion of social inclusion can bring various advantages and promote sales directly and indirectly. A direct positive influence can be observed in the service sector or in direct customer contact through the perception of service quality by customers. The reflection in the company of the diversity of society and customers makes a significant contribution to the acquisition and long-term retention of customers and the development of new customer segments. Indirect factors drive sales through more innovation. The diversity of the employees and the resulting sensitization make it easier to respond to customer needs. New or adapted products and services can open new market segments. Social inclusion offers the interesting opportunity to make the values of a company visible and thus makes a significant contribution to the creation of a strong brand and promotes the reputation

Boris Miethlich and Anett G. Oldenburg (2019), Journal of Marketing Research and Case Studies, DOI: $10.5171 / 2019.463316$ 
as a socially responsible company. If social inclusion, such as the employment of PWD, is not only understood as an image promotion, but the full potential is used, this can create competitive advantages, such as the creation of value. In consequence, this can lead to more sales and profitability. Social inclusion can be an important tool for differentiation, although customers respond most strongly to product-related CSR activities. If it is possible to make the commitment visible, this can be a central element of a strategy for market entry, even in supersaturated markets, for maintaining and gaining market share or for creating new market entry barriers.

Based on the knowledge gained, the following conclusions can be drawn: As employees and customers, PWD offer significant potential for business success, which to date has been largely untapped by companies. Strategy development at the normative level (core strategy) can help to close this potential gap, thus increasing business success and meeting the growing public expectation to take on social tasks. A positive side effect of CSR activities is the added value that can be achieved by society and companies because of increasing prosperity ("shared value"). Accordingly, CSR is to be regarded as a suitable instrument for product differentiation, enabling access to new markets and creating market entry barriers in the area of social factors. However, it is important that CSR is seen as a fundamental strategic thrust and not merely as an additional activity within the company. CSR can lead to a competitive advantage that is unique and above all sustainable.

\section{References}

1. Anselmsson, J. and Johansson, U. (2007), 'Corporate social responsibility and the positioning of grocery brands: An exploratory study of retailer and manufacturer brands at point of purchase', International Journal of Retail \& Distribution Management, 35 (10), 835-856.

2. Anselmsson, J., Bondesson, N. and Melin, F. (2016), 'Customer-based brand equity and human resource management image: Do retail customers really care about HRM and the employer brand?', European Journal of Marketing, 50 (7/8), 1185-1208.

3. Aytac, S., Bayram, N., Özenalp, A., Özgökçeler, S., Berkun, S., Ceylan, A. and Erturk, H. (2012), 'Flexible working and employment of people with disabilities at customs brokerage firms in Turkey: a social responsibility project', Procedia-Social and Behavioral Sciences, 65, 39-45.

4. Ball, P., Monaco, G., Schmeling, J., Schartz, H. and Blanck, P. (2005), 'Disability as diversity in fortune 100 companies', Behavioral Sciences and the Law, 23 (1), 97122.

5. Barnes, C. and Mercer, G. (2005), 'Disability, work, and welfare: Challenging the social exclusion of disabled people', Work, Employment and Society, 19 (3), 527545.

6. Baumann-Pauly, D., Wickert, C., Spence, L. J. and Scherer, A. G. (2013), 'Organizing Corporate Social Responsibility in Small and Large Firms: Size Matters', Journal of Business Ethics, 115 (4), 693-705.

7. Baumgartner, R. J. and Ebner, D. (2010), 'Corporate sustainability strategies: sustainability profiles and maturity levels', Sustainable Development, 18 (2), 76-89.

8. Bea, F. X. and Haas, J. (2016), Strategisches Management, utb, München.

9. Bennett, A. J. W. (2011), 'Learning to be job ready: Strategies for greater social inclusion in public sector Employment', Journal of Business Ethics, 104 (3), 347-359.

10. Bergius, S. (2005), Nachhaltiges Wirtschaften schont die Ressourcen und sichert das Geschäft, [Online], Handelsblatt, [January 01, 2019], Available: https://www.handelsblatt.com/unternehm en/industrie/nachhaltiges-wirtschaftenschont-die-ressourcen-und-sichert-dasgeschaeft-wer-verantwortung-zeigt-mussauch-verzichten/2513074.html. 
11. Berthoud, R. (2008), 'Disability employment penalties in Britain', Work, Employment and Society, 22 (1), 129-148.

12. Bhattacharya, C. B., Korschun, D. and Sen, S. (2009), 'Strengthening StakeholderCompany Relationships Through Mutually Beneficial Corporate Social Responsibility Initiatives', Journal of Business Ethics, 85 (S2), 257-272.

13. Boehe, D. M. and Barin Cruz, L. (2010), 'Corporate Social Responsibility, Product Differentiation Strategy and Export Performance', Journal of Business Ethics, 91 (S2), 325-346.

14. Branco, M. C. and Rodrigues, L. L. (2006), 'Corporate Social Responsibility and Resource-Based Perspectives', Journal of Business Ethics, 69 (2), 111-132.

15. Buys, N., Matthews, L. R. and Randall, C. (2015), 'Contemporary vocational rehabilitation in Australia', Disability and rehabilitation, 37 (9), 820-824.

16. Chen, X., Huang, R., Yang, Z. and Dube, L. (2018), 'CSR types and the moderating role of corporate competence', European Journal of Marketing, 52 (7/8), 1358-1386.

17. Collins, A. B. (2007), Opportunities and Obligations in Dealing with the Disabled Staff and Customers in Hospitality Industry, Tourism Management in the 21st Century, Chang, P. R. (ed), Nova Science Publishers Inc., New York.

18. Crane, A., Matten, D. and Spence, L. J. (2008), Corporate social responsibility: in a global context, Corporate social responsibility: Readings and cases in global context, Crane, A., Matten, D. and Spence, L. J. (ed), Routledge, New York.

19. Csillag, S. and Gyori, Z. (2016), '"Is there a place for me?" Employment of people with disabilities as part of csr strategy', Proceedings of the $4 \mathrm{~h}$ Strategica International Academic Conference: Opportunities and risks in the contemporary business environment, ISBN: 978-606-749-181-4, 20-21 October 2016, Bucharest, Romania, 860-872.
20. Csillag, S., Gyori, Z. and Matolay, R. (2018), Two Worlds Apart? Corporate Social Responsibility and Employment of People with Disabilities, The Critical State of Corporate Social Responsibility in Europe (Critical Studies on Corporate Responsibility, Governance and Sustainability, Volume 12), Tench, R., Jones, B. and Sun, W. (ed), Emerald Publishing Limited, Bingley.

21. Cullen, J. C., Silverstein, B. A. and Foley, M. P. (2008), 'Linking biomechanical workload and organizational practices to burnout and satisfaction', Journal of Business and Psychology, 23 (1-2), 63-71.

22. Dibben, P., James, P., Cunningham, I. and Smythe, D. (2002), 'Employers and employees with disabilities in the UK: An economically beneficial relationship?', International Journal of Social Economics, 29 (6), 453-467.

23. Du, S., Bhattacharya, C. B. and Sen, S. (2007), 'Reaping relational rewards from corporate social responsibility: The role of competitive positioning', International Journal of Research in Marketing, 24 (3), 224-241.

24. Dyda, D. J. (2008), 'Jobs change lives: Social capital and shared value exchange', Journal of Vocational Rehabilitation, 29 (3), 147-156.

25. Elkington, J. (2007), Corporate sustainability. In A to Z of Corporate Social Responsibility - A Complete Reference Guide to Concepts, Codes and Organisations, Visser, W., Matten, D. and Böhmer, K. (ed), John Wiley \& Sons Ltd, Chichester.

26. EC (2004), ABC of the main instruments of Corporate Social Responsibility, Office for Official Publications of the European Communities.

27. EC (2011), A renewed EU strategy 2011-14 for Corporate Social Responsibility, (Com/2011/0681/final), Communication from the commission to the european parliament, the council, the

Boris Miethlich and Anett G. Oldenburg (2019), Journal of Marketing Research and Case Studies, DOI: $10.5171 / 2019.463316$ 
european economic and social committee and the committee of the regions.

28. Gelashvili, V., Camacho-Miñano, M. M. and Segovia-Vargas, M. (2015), 'The Profitability of Socially Reponsible Companies: Public Subsidies for Sheltered Employment Centers', Ramon Llull Journal of Applied Ethics, (6), 111-123.

29. Graffam, J., Smith, K., Shinkfield, A. and Polzin, U. (2002), 'Employer benefits and costs of employing a person with a disability', Journal of Vocational Rehabilitation, 17(4), 251-263.

30. Gratzl, B. and Gumpfer, F. (2017), Interne CSR-Kommunikation: Fünf Praxisbeispiele international tätiger Schweizer Unternehmen, CSR und Interne Kommunikation, Wagner, R., Roschker, N. and Moutchnik, A. (ed), Springer Gabler, Berlin.

31. Gröschl, S. (2004), 'Current human resources practices affecting the employment of persons with disabilities in selected Toronto hotels: a case study', International Journal of Hospitality \& Tourism Administration, 5 (3), 15-30.

32. Gröschl, S. (2005), 'Persons with Disabilities: A Source of Nontraditional Labor for Canada's Hotel Industry', Cornell Hotel and Restaurant Administration Quarterly, 46 (2), 258-274.

33. Gröschl, S. (2007), 'An exploration of HR policies and practices affecting the integration of persons with disabilities in the hotel industry in major Canadian tourism destinations', International Journal of Hospitality Management, 26 (3), 666-686.

34. Gröschl, S. (2013), 'Presumed incapable: Exploring the validity of negative judgments about persons with disabilities and their employability in hotel operations', Cornell Hospitality Quarterly, 54 (2), 114123.

35. Gyori, Z. and Ocsai, A. (2014), 'Ecologically-oriented enterprises in Hungary', World Review of
Entrepreneurship, Management and Sustainable Development, 10 (1), 52-65.

36. Hidegh, A. L. and Csillag, S. (2013), 'Toward "mental accessibility": changing the mental obstacles that future Human Resource Management practitioners have about the employment of people with disabilities', Human Resource Development International, 16 (1), 22-39.

37. Hull, R. (2007), Dow Chemical Company, Hidden Talent: How Leading Companies Hire, Retain, and Benefit from People with Disabilities, Lengnick-Hall, M. (ed), Praeger, Westport.

38. Jones, P. and Schmidt, R. A. (2004), 'Retail employment and disability', International Journal of Retail \& Distribution Management, 32 (9), 426-429.

39. Kalargyrou, V. (2014), 'Gaining a competitive advantage with disability inclusion initiatives', Journal of Human Resources in Hospitality \& Tourism, 13 (2), 120-145.

40. Kerth, K., Asum, H. and Stich, V. (2015), Die besten Strategietools in der Praxis: Welche Werkzeuge brauche ich wann? Wie wende ich sie an? Wo liegen die Grenzen?, Carl Hanser Verlag GmbH Co KG, München.

41. Klimczuk, A. (2013), 'Contemporary Social Policy Towards Disability and Disabled People', Pogranicze. Studia Spoleczne, Tom XXII, 185-200.

42. Kraus, P. and Brtitzelmaier, B. (2012), 'A literature review on corporate social responsibility: definitions, theories and recent empirical research', International Journal of Management Cases, 14 (4), 282296.

43. Kuznetsova, Y. (2012), 'Inclusive corporate culture and employment of persons with disabilities: analysis of CSR strategies of multinational enterprises in Norway and the UK', Proceedings of the 13th UFHRD International Conference on Human Resource Development Research and Practice Across Europe: The future of HRD - 2020 and beyond: challenges and

Boris Miethlich and Anett G. Oldenburg (2019), Journal of Marketing Research and Case Studies, DOI: $10.5171 / 2019.463316$ 
opportunities, 23-25 May 2012, Famalicao, Portugal.

44. Kuznetsova, Y. and Bento, J. P. C. (2018), 'Workplace adaptations promoting the inclusion of persons with disabilities in mainstream employment: a case-study on employers' responses in Norway', Social Inclusion, 6 (2), 34-45.

45. Kuznetsova, Y. and Yalcin, B. (2017), 'Inclusion of persons with disabilities in mainstream employment: is it really all about the money? A case study of four large companies in Norway and Sweden', Disability \& Society, 32 (2), 233-253.

46. Lee, M. D. P. (2008), 'A review of the theories of corporate social responsibility: Its evolutionary path and the road ahead', International Journal of Management Reviews, 10 (1), 53-73.

47. Leitschuh, H. (2008), 'CSR ist gut, nachhaltig Wirtschaften ist besser', Uwf UmweltWirtschaftsForum, 16 (1), 45-48.

48. Lindsay, S., Cagliostro, E., Albarico, M., Mortaji, N. and Karon, L. (2018), 'A Systematic Review of the Benefits of Hiring People with Disabilities', Journal of Occupational Rehabilitation, 28 (4), 634655.

49. Lysaght, R., Ouellette-Kuntz, H. and Lin, C. J. (2012), 'Untapped potential: Perspectives on the employment of people with intellectual disability', Work, 41 (4), 409-422.

50. Maignan, I. and Ferrell, O. C. (2004), 'Corporate Social Responsibility and Marketing: An Integrative Framework', Journal of the Academy of Marketing Science, 32 (1), 3-19.

51. Manaf, A. R. A., Othman, S. Z., Saad, Z. M., Jamaluddin, Z. and Noor, A. A. M. (2018), 'Employability of Persons with Disabilities: Job Coaches' Perspectives', International Journal of Academic Research in Business and Social Sciences, 8 (6), 254-269.

52. Markel, K. S. and Barclay, L. A. (2009), 'Addressing the underemployment of persons with disabilities:
Recommendations for expanding organizational social responsibility', Employee Responsibilities and Rights Journal, 21 (4), 305-318.

53. Marsden, C. and Andriof, J. (1998), 'Towards an understanding of corporate citizenship and how to influence it', Citizenship Studies, 2 (2), 329-352.

54. Matten, D. and Crane, A. (2007). Business Ethics. In A to Z of Corporate Social Responsibility - A Complete Reference Guide to Concepts, Codes and Organisations, Visser, W., Matten, D. and Böhmer, K. (ed), John Wiley \& Sons Ltd, Chichester.

55. Matten, D. and Moon, J. (2008), 'Implicit" and "Explicit" CSR: A Conceptual Framework for a Comparative Understanding of Corporate Social Responsibility', Academy of Management Review, 33 (2), 404-424.

56. Mayring, P. (2015), Qualitative Inhaltsanalyse, Beltz, Basel.

57. Miethlich, B. (2018), 'Comparing the impact of employment of persons with disabilities and vocational rehabilitation on companies', Proceedings of the 10th Biannual CER Comparative European Research Conference - International Scientific Conference for Ph.D. students of EU countries, ISBN: 978-0-9935191-9-2, 29-31 October 2018, London, United Kingdom, 43-47.

58. Miethlich, B. and Šlahor, L. (2018a), 'Creating shared value through implementing vocational rehabilitation in the corporate social responsibility strategy: A literature review', Proceedings of the 32nd IBIMA International Business Information Management Association Conference - Vision 2020: Sustainable Economic Development and Application of Innovation Management from Regional expansion to Global Growth, ISBN: 978-09998551-1-9, 15-16 November 2018, Seville, Spain, 1444-1460.

59. Miethlich, B. and Šlahor, L. (2018b), 'Employment of persons with disabilities as

Boris Miethlich and Anett G. Oldenburg (2019), Journal of Marketing Research and Case Studies, DOI: $10.5171 / 2019.463316$ 
a corporate social responsibility initiative: Necessity and variants of implementation', Proceedings of the 6th CBU International Conference on Innovations in Science and Education, ISBN: 978-80-270-5037-6, 2123 March 2018, Prague, Czech Republic, 350-355.

60. Migliaccio, G. (2016), 'ICT for disability management in the net economy', International Journal of Globalisation and Small Business, 8 (1), 51-72.

61. Millington, M. J., Miller, D. M., Asner-Self, K. K. and Linkowski, D. (2003), The business perspective on employers, disability, and vocational rehabilitation, Work and disability, Szymanski, E. and Parker, R. (ed), PRO-ED, Austin.

62. Miller, F. D. and Ahrens, J. (1993), The social responsibility of corporations, Business Ethics: A Philosophical Reader, White, T. I. (ed), Prentice Hall, New Jersey.

63. Mintzberg, H., Ghoshal, S., Lampel, J. and Quinn, J. B. (2003), The strategy process: concepts, contexts, cases. Pearson education, Essex.

64. Monachino, M. S. and Moreira, P. (2014), 'Corporate social responsibility and health promotion debate: An international review on the potential role of corporations', International Journal of Healthcare Management, 7 (1), 53-59.

65. Morger, W. (2006), The point of view of the insurance company, Vocational Rehabilitation, Gobelet, C. and Franchignoni, F. (ed), Springer, Paris.

66. Munduate, L., Di Marco, D., MartinezCorts, I., Arenas, A. and Gamero, N. (2014), 'Rebuilding the social dialogue and promoting inclusive organizations. A tool for social innovation in times of crisis', Papeles Del Psicólogo, 35 (2), 122-129.

67. ODEP. (2018), How does the federal government define "disability"?, [Online], U.S. Department of Labor: Office of Disability Employment Policy. [January 01, 2019],

Available: https://www.dol.gov/odep/faqs/general.h tm\#3.

68. Papula, J., Papulová, Z. and Papula, J. (2014), Konkurenčné stratégie: tradičné prístupy vs. nové pohl'ady a techniky, Wolters Kluwer, Bratislava, Slovak Republic.

69. Papulova, E. and Papulova, Z. (2006), 'Competitive strategy and competitive advantages of small and midsized manufacturing enterprises in Slovakia', $E$ Leader Slovakia, 1-6.

70. Park, S. Y. and Lee, S. (2009), 'Financial rewards for social responsibility: A mixed picture for restaurant companies', Cornell Hospitality Quarterly, 50 (2), 168-179.

71. Peloza, J. and Shang, J. (2011), 'How can corporate social responsibility activities create value for stakeholders? A systematic review', Journal of the Academy of Marketing Science, 39 (1), 117-135.

72. Perera, L. C. R. and Hewege, C. R. (2007), 'Corporate social responsibility and business strategy: A case study of a Japanese firm shifting from environmentalism to strategic CSR', Proceedings of the 21st ANZAM 2007 Conference: Managing our Intellectual and Social Capital, ISBN: 9781863081412, 4-7 December 2007, Wentworth, Sydney, 1-15.

73. Pérez, F. J., Romeo, M. and Yepes-Baldó, M. (2018), 'The corporate social responsibility policies for the inclusion of people with disabilities as predictors of employees' identification, commitment and absenteeism', Anales De Psicología, 34 (1), 101-107.

74. Porter, M. E. and Kramer, M. R. (2006), 'Strategy and Society: The Link Between Competitive Advantage and Corporate Social Responsibility', Harvard Business Review, 84 (12), 78-92.

75. Porter, M. E. (2008), Competitive strategy: Techniques for analyzing industries and competitors, Free Press, New York. 
76. Rosenbaum, M. S., Baniya, R. and SegerGuttmann, T. (2017), 'Customer responses towards disabled frontline employees', International Journal of Retail \& Distribution Management, 45 (4), 385-403.

77. Sandler, L. A. and Blanck, P. (2005), 'The quest to make accessibility a corporate article of faith at Microsoft: case study of corporate culture and human resource dimensions', Behavioral Sciences \& the Law, 23 (1), 39-64.

78. Schneider, A. (2015), Reifegradmodell CSR - eine Begriffsklärung und -abgrenzung, Corporate Social Responsibility: Verantwortungsvolle

Unternehmensführung in Theorie und Praxis, Schneider, A. \& Schmidpeter, R. (ed), Springer, Berlin.

79. Schur, L., Kruse, D. and Blanck, P. (2005), 'Corporate culture and the employment of persons with disabilities', Behavioral Sciences \& the Law, 23 (1), 3-20.

80. Schur, L., Kruse, D., Blasi, J. and Blanck, P. (2009), 'Is Disability Disabling in All Workplaces? Workplace Disparities and Corporate Culture', Industrial Relations, 48 (3), 381-410.

81. Schur, L., Nishii, L., Adya, M., Kruse, D., Bruyère, S. M. and Blanck, P. (2014), 'Accommodating Employees With and Without Disabilities', HR Science Forum, 53 (4), 593-621.

82. Schwartz, M. S. and Carroll, A. B. (2003), 'Corporate Social Responsibility: A ThreeDomain Approach', Business Ethics Quarterly, 13 (4), 503-530.

83. Segovia-San-Juan, A. I., Saavedra, I. and Fernández-de-Tejada, V. (2017), 'Analyzing Disability in Socially Responsible Companies', Social Indicators Research, 130 (2), 617-645.

84. Seino, K., Nomoto, A., Takezawa, T. and Boeltzig-Brown, H. (2017), The diversity management for employment of the persons with disabilities: evidence of vocational rehabilitation in the united states and japan, Handbook of Research on Human
Factors, Contemporary Workforce Development, Christiansen, B. and Chandan, H. C. (ed), Business Science Reference, Hershey.

85. Sen, S., Bhattacharya, C. B. and Korschun, D. (2006), 'The Role of Corporate Social Responsibility in Strengthening Multiple Stakeholder Relationships: A Field Experiment', Journal of the Academy of Marketing Science, 34 (2), 158-166.

86. Smith, N. C. (2003), 'Corporate Social Responsibility: Whether or How?', California Management Review, 45 (4), 5276.

87. Vilchinsky, N. and Findler, L. (2004), 'Attitudes toward Israel's equal rights for PWD law: A multiperspective approach', Rehabilitation Psychology, 49 (4), 309-316.

88. Wang, H., Tong, L., Takeuchi, R. and George, G. (2016), 'Corporate social responsibility: an overview and new research directions thematic issue on corporate social responsibility', Academy of Management Journal, 59 (2), 534-544.

89. Wells, S. J. (2008), 'Counting on workers with disabilities', Human Resource Management International Digest, 16 (6), 44-48.

90. Werner, W. J. (2009), 'Corporate social responsibility initiatives addressing social exclusion in Bangladesh', Journal of Health, Population, and Nutrition, 27 (4), 545.

91. Wiggett-Barnard, C. and Swartz, L. (2012), 'What facilitates the entry of persons with disabilities into South African companies?', Disability and Rehabilitation, 34 (12), 1016-1023.

92. Woodhams, C. and Danieli, A. (2000), 'Disability and diversity - a difference too far?', Personnel Review, 29 (3), 402-417.

93. Wynne, R. and McAnaney, D. (2004), Employment and disability: Back to work strategies, Employment and disability: Back to work strategies, Cornell University, Ithaca. 